\title{
Competition and profitability: impacts on stability in Chinese banking
}

\author{
Yong Tan*1, Marco Chi Keung Lau* and Giray Gozgor** \\ *Department of Accountancy, Finance, and Economics, Huddersfield Business School, University of \\ Huddersfield, Huddersfield, Queensgate, HD1 3DH, UK. \\ ${ }^{* 1}$ corresponding author, email: a.y.tan@hud.ac.uk \\ **Department of International Relations, Istanbul Medeniyet University, Istanbul, 34700, Turkey.
}

\begin{abstract}
This study contributes to the banking literature by testing the joint impacts of profitability and industry environment on several types of risk (credit risk, liquidity risk, capital risk, and insolvency risk) in a sample of Chinese commercial banks over the period 2003 to 2015 . The results show that a more highly developed banking sector increases the liquidity risk and credit risk of Chinese commercial banks but decreases their capital risk. It is further suggested that profitability may lead to a reduction in credit risk and insolvency risk. The findings from the current study thus have important policy implications in terms of improving stability in the Chinese banking industry.
\end{abstract}

JEL classification: G21, C33, C14

Keywords: competition, risk, profitability, Chinese banking 


\section{Introduction}

China's economic development has recently attracted the attention of the rest of the world. During the period from 2003 to 2015, China had an average annual GDP growth rate of over 9.8\%, and the Chinese banking sector has seen sustainable and healthy development through several rounds of banking reforms initiated by the government since 1978. The primary purpose of these banking reforms was to increase competitive conditions, enhance stability, and improve the performance of the Chinese banking sector. State-owned commercial banks (SOCBs) dominate the industry; however, according to statistics from the China Banking Regulatory Commission (CBRC), the share of SOCB assets in terms of total banking sector assets decreased between 2003 and 2015, reaching a low of $39.2 \%$. In contrast, joint-stock commercial banks (JSCBs) and city commercial banks (CCBs) have kept increasing in size, and by 2015, they held $18.2 \%$ and $18.5 \%$ of total banking sector assets, respectively. This strongly suggests that competitive conditions in the Chinese banking sector have improved.

The Chinese banking industry reduced the proportion of credit risk undertaken significantly between 2003 to 2009, reaching a non-performing loan ratio of $1.6 \%$; although this ratio slightly increased in 2010, to $2.4 \%$, it again dropped below $2 \%$ over the period 2011 to 2015 . The Chinese banking industry also reduced its capital risk: CBRC statistics show that, by the end of 2015, the average capital adequacy ratio of Chinese banks was $13.45 \%$, an increase of $0.27 \%$ compared to the previous year. In addition, the liquidity ratio of Chinese commercial banks was $48.01 \%$ by the end of 2015 , an increase of $1.57 \%$ year-on-year.

Research investigating competitive conditions in the Chinese banking sector has already emerged (Yuan, 2006; Masood and Sergi, 2011; Fu, 2009; Park, 2013; Tan and Floros, 2013a; Tan, 2014, Tan, 2017), along with several studies examining the effect of competition on risk-taking 
behaviours in the banking industry (Fu et al., 2014; Liu and Wilson, 2013; Liu et al., 2013; Liu et al., 2012); however, only a few studies have examined the impact of competition on risk-taking behaviours in the Chinese banking industry (Tan, 2013, Tan and Floros, 2014, Tan, 2014, Hu and Xie, 2016; Tan and Anchor, 2017a; Liu, 2017). Several rounds of banking reforms have occurred in China, not only with the aim of improving competitive conditions and reducing the risk-taking behaviours of Chinese commercial banks but also to improve the performance of the Chinese banking industry as a whole. Many empirical studies have thus examined the performance of Chinese commercial banks in light of these (Garcia-Herrero et al., 2009; Tan and Floros, 2013a; Tan, 2014, Fungacova et al., 2013). In particular, some research has specifically tested the impact of competition on the performance of the Chinese commercial banks (Tan and Anchor, 2017b; Tan et al., 2017; Tan, 2017). However, empirical investigations of the impact of profitability on different types of risk (credit risk, liquidity risk, capital risk, and insolvency risk) in the banking industry are also relatively scarce.

Banks with higher levels of profitability generally have more complete monitoring and management mechanisms (Tan and Floros, 2014). This helps reduce the volume of non-performing loans and thus leads to a reduction in the level of credit risk. The Basel Committee on Bank Supervision (2000) argued that

1) Banks must emplace systems for monitoring the condition of individual credits, including determining the adequacy of provisions and reserves; and

2) Banks must emplace systems for monitoring the overall composition and quality of their credit portfolios. 
Thus, profitability may be expected to have a significant and negative impact on credit risk. It is expected that banks with higher levels of profitability will retain a larger number of funds to replenish their capital based on the idea that large amounts of capital improve bank stability.

This is in line with Osbourn et al. (2017), who suggested that banks with higher levels of profitability have more incentives to limit risk-taking by holding higher levels of capital. This is further supported by Demsetz et al. (1996) and Hellmann et al. (2000), who argued that the large interest margins derived from market power or established relationships can reduce the level of risk undertaken by banks at the expense of liability holders, leading to a further reduction in the level of capital risk. Thus, profitability is predicted to have a significant and negative impact on capital risk. Higher levels of capital in banks with higher levels of profitability enable them to fully engage in a variety of short-term and long-term loan transactions, and this leads to a reduction in the level of bank liquidity, leading to a higher level of liquidity risk.

Loans are still the primary income source in the Chinese banking industry, and although the position come with a level of risk, banks with higher profitability are expected to have a higher level of ability to absorb the negative shocks derived from loan business. Thus, banks with higher profitability are likely to increase the volume of loan businesses engaged in within the economy. Tan and Anchor (2017a) argue that an increase in the volume of loan business will increase both the short-term credit allocation and long-term credit allocation, which in turn will decrease liquidity levels and increase bank liquidity risk. Thus, it is expected that profitability will have a significant and positive impact on liquidity risk.

Finally, banks with higher levels of profitability have a higher ability to meet their obligations when these come due. Traditionally, banking literature uses the Z-score to measure insolvency risk (Tan and Anchor, 2016), which is calculated as follows: 


\section{1) Calculate the return on assets plus capitalization;}

2) Calculate the standard deviation of return on assets;

\section{3) Divide 1) by 2).}

A higher Z-score indicates lower levels of insolvency risk. Profitability is thus predicted to have a significant and negative impact on insolvency risk.

This work aims to investigate the joint impacts of profitability and industry environment on stability in the Chinese banking industry. This study thus contributes to the empirical banking literature in several ways: the current study is the first piece of research to examine the impact of profitability on different types of risk (credit risk, liquidity risk, capital risk, and insolvency risk) in the Chinese banking industry; the current study also fills a gap in the empirical literature by explicitly investigating the impacts of relevant industry-specific variables on different types of risk of Chinese commercial banks. Overall, this paper contributes to the banking literature by specifically examining the impacts of banking sector development and stock market development on different types of risk in the Chinese banking industry.

A higher level of banking sector development indicates a more highly developed demand for banking services (Fang et al., 2019). Fang et al. (2019) thus used banking sector development as an industry-specific variable to test for impact on bank profitability in China; they found that the effect was significant and positive. They thus argued that a more highly developed banking sector in China would increase demand for non-interest generating businesses. Tan and Floros (2012) further claimed that such an increase in demand for services would attract more competitors to the market, causing a lower level of competition in interest-generating businesses as more effort and time were invested in non-interest generating businesses. In such circumstances, Chinese 
commercial banks are likely to be more selective in terms of credit granted to different companies, and this enhanced and more careful selection is predicted to reduce the volume of non-performing loans and further reduce the credit risk of Chinese commercial banks. However, higher credit provision by the banking sector could arise due to an increase in supply of credit by Chinese banks rather than demand from businesses. Under this scenario, the banks might not conduct proper due diligence when extending credit due to the existence of a buyer market where supply exceeds demand; thus, the relationship between banking sector development and the level of credit risk could also be positive.

Consequently, there can be no a priori expectations regarding the impact of banking sector development on credit risk. A large demand for banking services, including traditional loan business, should induce Chinese commercial banks to engage in larger volumes of long-term and short-term loan business. This will result in a reduction in bank liquidity and further lead to an increase in the level of liquidity risk. Large volumes of other types of businesses engaged in by the Chinese commercial banks are more likely to increase bank profitability significantly, and Chinese commercial banks will retain a certain proportion of these profits to replenish their capital levels. It is thus expected that higher banking sector development should reduce the capital risk of Chinese commercial banks. Large profits made by Chinese commercial banks, derived from large volumes and variety of businesses engaged in, will further lead to an increase in banks' ability to absorb different external risks and meet their relevant obligations. Thus, it is expected that a more highly developed banking sector will lead to a reduction in the insolvency risk of Chinese commercial banks. 
A more highly developed stock market removes a large amount of loan business from commercial banks (Tan, 2019). Tan (2019) thus used stock market development as a control variable to investigate its impact on bank profitability. The results showed that a more highly developed stock market leads to a decrease in the average level of bank profitability. Tan (2019) argued that, in a more developed stock market, investors are more likely to invest money in the stock market rather than saving it in the bank. At a company level, companies are also more likely to raise funds from the stock market rather than getting bank loans. As loans are one of the leading businesses engaged in by Chinese commercial banks, this has a significant impact on the income of Chinese commercial banks. Thus, to increase the volume of loan business, Chinese commercial banks may reduce their requirements for granting credit to certain companies, and in some cases, even companies with relatively low credit ratings will be able to get bank loans. This leads to an increase in the volume of non-performing loans and further leads to an increase in the level of credit risk. It is therefore expected that stock market development has a significant and positive impact on credit risk (see Figure 1).

As discussed earlier, because of stronger competition from a more highly developed stock market, Chinese commercial banks are likely to engage in a lower volume of long-term and short-term loan business, further leading to an increase in liquidity levels and a reduction in liquidity risk. Chinese commercial banks will also need to use capital to write-off non-performing loans derived from the more developed stock market; it is thus expected that the impact of stock market development on capital risk will be significant and positive. Finally, large volumes of nonperforming loans mean that Chinese commercial banks will have lower volumes of interest income; this increases their difficulty in terms of meeting their obligations. Thus, it is expected that a more 
highly developed stock market will lead to an increase in the level of insolvency risk for Chinese commercial banks.

$$
\text { <<Figure 1--- about here>> }
$$

The preliminary findings of the current study show that Chinese commercial banks with higher levels of profitability have lower credit risk and insolvency risk. Furthermore, the results suggest that a more developed banking market increases both credit risk and liquidity risk for Chinese banks, while decreasing their capital risk.

This paper is structured as follows: Section 2 provides an institutional background for the Chinese banking industry. Section 3 reviews the empirical theory and literature on risk-taking behaviours by Chinese commercial banks. Section 4 presents the methodology and data used in the paper. Sections 5 and 6 discuss and explain the results, including the application of numerous robustness checks. Finally, a conclusion and summary are provided in section 7.

\section{Institutional background}

China's banking system has undergone several rounds of reforms, the purpose of which was to improve banking stability and to increase competitive conditions, as well as to improve the competitive power and performance of Chinese commercial banks overall. To enhance the stability of the Chinese banking industry, the China Banking Regulatory Commission (CBRC) was established in 2003. This commission is mainly responsible for supervising commercial bank operations; formulating rules and regulations; authorising the establishment of, changes to, termination of , and business scope of banking institutions; and conducting both on-site examination and off-site surveillance of bank operations (Tan and Floros, 2018). 
In addition to establishing the $\mathrm{CBRC}$, the Chinese government reduced the risk for Chinese commercial banks by writing off non-performing loans of SOCBs using four asset management companies. There were two instances of non-performing loan write offs, in 2004 and again in 2005 , and the use of asset management companies significantly reduced the number of non-performing loans with SOCBs in China (Tan and Anchor, 2017a).

The second purpose of Chinese banking reforms was to increase competitive conditions in the Chinese banking industry. The Chinese government along with the banking regulatory authority increased competition in the Chinese banking industry by gradually releasing the restrictions on foreign banks, which had previously prevented these institutions from engaging in banking activities in China. beginning in 2001, foreign banks were allowed to provide foreign currency services to both Chinese and foreign enterprises and individuals all over the country; however, they were only allowed to offer local currency business to foreign enterprises and overseas individuals in specific cities or areas in China. Later, this restriction was gradually eased, and the number of cities and areas in which foreign banks are allowed to conduct local currency business increased on a year-by-year basis. Foreign banks were finally also allowed to provide local currency business to domestic Chinese enterprises as well as to Chinese individuals. By the end of 2006, foreign banks were treated in the same manner as the domestic Chinese commercial banks, and this equal treatment significantly improved the competitive conditions in the Chinese banking industry (Tan, 2016).

The banking reforms in China aimed to increase the competitive power and performance of Chinese commercial banks. To further increase the competitive strength of Chinese commercial banks, the Chinese government also injected capital into its SOCBs and JSCBs. In 2003, capital 
to the sum of US\$ 42.5 billion was injected into the Bank of China and China Construction Bank, and in 2004, US\$ 15 billion in capital was injected into the Industrial and Commercial Bank of China and 2.5 billion RMB was similarly injected into the Bank of Communication. In 2005 and 2006, capital of 30 billion RMB was injected into the China Everbright Bank, and, finally, the Agricultural Bank of China received a capital injection of 130 billion RMB in 2008. These capital injections were intended to significantly improve the competitive power of Chinese commercial banks (Tan, 2016).

As part of the drive to improve the performance of Chinese commercial banks, the banks started attempting to attract foreign strategic investors. By the end of 2003, five Chinese commercial banks had successfully attracted seven foreign strategic investors . In 2004, HSBC purchased a $19.9 \%$ share of the Bank of Communication, which was the most significant foreign bank purchase of domestic bank shares at that time, and only $0.1 \%$ below the maximum shareholding percentage by foreign strategic investors allowed by the CBRC. Between 2004 and 2005, the number of foreign strategic investors kept increasing, until there were around 20 foreign strategic investors in 14 Chinese commercial banks. This number further increased to 33 foreign strategic investors purchasing shares from 25 domestic commercial banks by the end of 2007, and by the end of 2011, the total number of foreign investors was 57 , with the number of domestic commercial banks involved being 36 (Tan, 2016).

The available banking data includes information for 100 Chinese commercial banks (5 SOCBs, 12 JSCBs, and $83 \mathrm{CCBs}$ ) for the period 2003 to 2015. As not all selected banks have available information for all years, this paper has opted for an unbalanced panel dataset in order to protect the degrees of freedom. With regard to data sources, data was collected from Bankscope and the 
CBRC annual reports, as well as the World Bank database. Table 1 describes the variables examined in this study and their measurement, while Table 2 shows the summary statistics of the variables. These statistics show that the liquidity risk undertaken by Chinese commercial banks is smaller than the credit risk and capital risk. These higher levels of credit risk taken by Chinese commercial banks can be attributed to the fact that, during 2003 to 2006 , there were large volumes of non-performing loans in many SOCBs, especially in the Agricultural Bank of China, while the large difference in capital risk can be attributed to the opening of a single joint-stock commercial bank, the China Bohai Bank, in 2006, which had a total regulatory capital ratio of over $60 \%$.

In terms of other bank-specific variables, the results indicate that Chinese banks have large differences in terms of the degree of diversification of activities engaged in, while the difference in the profitability among Chinese banks is relatively small. Differences in bank size occur as SOCBs are bigger than JSCBs, while CCBs are even smaller. The results further show that there is stronger volatility concerning stock market development than banking sector development and macroeconomic environment. The stronger volatility of stock market development can be mainly attributed to the segregation reform initiated by the Chinese government in 2005 , which led to a substantial number of companies being listed on the stock exchange. By the end of 2007, there were 1,550 listed companies on the Shanghai and Hong Kong stock exchanges, to a value of 32.71 billion RMB, accounting for $132.6 \%$ of GDP that year, while prior to 2005, stock market development was only in its very early stages.

This led to investigation of differences in bank size, bank profitability, and bank diversification across different ownership types of Chinese commercial banks on an annual basis over the examined period, the results of which are shown in Figure 2. SOCBs were the largest bank ownership type in China over the examined period, followed by JSCBs; CCBs were the smallest. 
However, JSCBs demonstrated the lowest profitability over the examined period, while the difference in bank profitability between SOCBs and CCBs was quite small. This can be mainly attributed to the fact that SOCBs and CCBs are supported by central and local government, while the joint-ownership characteristic of JSCBs means they face a higher level of competition, and it is more difficult for them to increase income and profitability. Finally, SOCBs were the most diversified banking group compared to the other types; while CCBs were more diversified than JSCBs over the period 2003 to 2008, for the rest of the examined period, JSCBs exceeded CCBs in diversity ${ }^{1}$.

$$
\begin{aligned}
& \text { <<Table 1--about here>> } \\
& \text { <<Table 2---about here>> } \\
& \text { <<Figure 2---about here>> }
\end{aligned}
$$

\section{Literature Review}

The competition-fragility hypothesis argues that banks can withstand shocks and decrease risktaking behaviour in less competitive environments as these allow banks to earn higher profits through monopoly rents (Allen and Gale, 2004; Boyd and De Nicole, 2005). The competitionstability view, however, suggests that in a less competitive banking market, banks charge higher interest rates, which increase the probability of defaults on loan repayments.

\footnotetext{
${ }^{1}$ There some scepticism about these figures, and many analysts have accused Chinese authorities of under-reporting bank risk as a way to artificially support confidence in Chinese banks. This data reported by CBRC was thus cross checked with data collected from Bankscope. The information from Bankscope is sourced by the Bureau Van Dijk from a combination of annual reports, information providers, and regulatory sources, and more than 200 validation controls are applied to the data. The data is checked on an entity by entity basis and reviewed regularly. The data used in the current paper is thus not only from CBRC, but also from Bankscope and the World Bank database, as this use of different data sources helps guarantee the accuracy of the data.
} 
A few research studies have investigated the impact of competition on risk-taking behaviours in the Chinese banking industry: Tan (2013) investigated the impact of competition on risk in the Chinese banking industry over the period 2003 to 2009. Competition was measured by two indicators, the Panzar-Rosse H statistic and the Lerner index, while both insolvency risk and credit risk were considered, as reflected by the Z-score and the ratio of loan loss provision to total loans, respectively. The impact was examined under the Generalized Method of Moments estimator, and the results indicate no robust impact of competition on risk in the Chinese banking industry.

Using a seemingly unrelated regression analysis, Tan and Floros (2014) investigated the interrelationships between risk, competition, and profitability for a sample of Chinese commercial banks over the period 2003 to 2009. The Lerner index and profitability measure for the competitive condition was measured by return on assets (ROA) and return on equity (ROE). Four risk indicators were used: Z-score, loan loss provision to total loans ratio, the volatility of ROA, and the volatility of ROE. These different risk indicators mainly reflect credit risk and insolvency risk. The results did not show any robust impact of competition on risk-taking behaviours among Chinese banks; further, there was no clear and significant impact from profitability on risk in the Chinese banking industry.

Using three different competition indicators, the Panzar-Rosse H statistic, Lerner index, and the three-bank concentration ratio, Tan (2014) investigated the competitive conditions in the Chinese banking industry using a sample of Chinese commercial banks during the period 2003 to 2011. This investigation further tested the impact of competition on the risk-taking behaviours of Chinese commercial banks, with risk measured and cross-checked using three different indicators: the ratio of loan-loss provision to total loans, Z-score, and stability inefficiency. The results showed that a 
higher level of competition in the Chinese banking industry leads to a higher volume of loan loss provision among Chinese commercial banks.

Using three competition indicators, the concentration ratio, Herfindahl-Hirschman index, and Boone indicator, and one insolvency risk indicator, the Z-score, Hu and Xie (2016) investigated the impact of competition on risk for a sample of 14 listed Chinese commercial banks for the period 2004 to 2014 under a structural regression model. Their results indicated that there was a significant and negative impact from competition on risk in the Chinese banking industry.

Liu (2017) tested the impact of competition on risk for a sample of 16 listed banks from the fourth quarter of 2005 to the second quarter of 2016. Two risk indicators were considered in the study, the Z-score and the proportion of weighted risk assets to total assets, while the competitive conditions in the Chinese banking industry were measured using the bank concentration ratio. A fixed-effect estimation was used as the selected econometric technique, and the findings suggested that a higher level of competition leads to an increase in the proportion of risk assets to total assets and also an increase in the bank's likelihood of bankruptcy, reducing the overall operating stability of the bank.

Rather than using the traditional Lerner index, Tan and Anchor (2017a) used an efficiencyadjusted Lerner index to measure the competitive conditions in the Chinese banking industry for the period 2003 to 2013. The authors then investigated the impact of competition on different types of risk (credit risk, liquidity risk, capital risk, and insolvency risk) by applying the Generalized Method of Moments (GMM) system estimator. The results showed that a higher level of competition leads to higher credit risk, higher liquidity risk, and higher capital risk, but lower insolvency risk. 
Overall, although there are a few pieces of research examining the impact of competition on different types of risk in the Chinese banking industry, there has been no empirical study explicitly testing the effects of profitability and industry environment on different types of risk among Chinese commercial banks. The current study thus fills a gap from this perspective, though the results generated from this paper are consistent with the findings of others once cross-checked by a number of different robustness tests.

\section{Methodology and data}

\subsection{Estimation of different types of risk in the Chinese banking industry}

This paper investigates different kinds of risk-taking behaviour in the Chinese banking industry including credit risk, liquidity risk, and capital risk, as well as insolvency risk. In terms of measures examined, the ratio of non-performing loans to total loans is used to measure the credit risk, and a higher figure for this ratio indicates higher credit risk (Fiordelisi et al., 2011; Beck et al., 2013; Broll et al., 2018). The ratio of liquid assets to total assets is used to measure the liquidity risk; the higher this ratio, the lower the bank's liquidity risk (Brissimis et al., 2008; Goddard et al., 2009). The total regulatory capital ratio is used to measure the capital risk, and higher total regulatory capital ratios indicate that banks have lower capital risk (Kleff and Weber, 2008; Francis and Osborne, 2012). The final type of risk-taking behaviour examined is insolvency risk, which is measured using the Z-score ${ }^{2}$ (Konara et al., 2019; Iannotta et al., 2007).

\footnotetext{
${ }^{2} \mathrm{Z}$-score is calculated as $Z=\frac{R O A+E / A}{\sigma(R O A)}$ where ROA is the bank's Return on Assets, E/A is the ratio of equity over total assets, and $\sigma(R O A)$ is the standard deviation of Return on Assets.
} 


\subsection{Estimation of the impacts of profitability and industry environment on different types of risk}

The following equation was used to test the joint impacts of profitability and industry environment on different types of risk in the Chinese banking industry under the fixed-effects model with robust standard errors clustered by bank estimations:

RISK $_{i t}=a++$ bcompetition $_{i t}+$ csize $_{i t}+$ ddiverse $_{i t}+$ eprofit $_{i t}+f B S D_{i}+g S M D_{i}+$

hinflation $_{i}+i G D P G_{i}+v_{i}+v_{i}+\varepsilon_{i t}$

where subscripts $i$ and $j$ represent specific banks operating in a particular year; RISK is different risk conditions in the Chinese banking industry, that is credit risk, liquidity risk, capital risk, and insolvency risk; and competition is the level of competition in the Chinese banking industry based on the Lerner index ${ }^{3}$. Three bank-specific variables are controlled for: bank size (size) (natural logarithm of total assets), bank diversification (diverse) (the ratio of non-interest income to gross revenue, and profitability (profit) (Return on Assets (ROA). The study also considers two industryspecific variables, banking sector development or BSD (the ratio of domestic credit offered to the private sector by banks to GDP) and stock market development or SMD (the ratio of the market capitalisation of listed companies to GDP ${ }^{4}$ ). Finally, \# two macroeconomic variables are included, which are inflation (annual inflation rate) and yearly GDP growth rate (GDPG). Of the other terms, $v_{i}$ represents bank fixed-effects, $v_{i}$ is the year fixed-effects, and $\varepsilon_{i t}$ represents the error-term.

\footnotetext{
${ }^{3}$ Please see appendix for the estimation of Lerner index.

${ }^{4}$ Larger ratios indicate that either there is an increase in the value of existing firms listed in the stock market or there is an increase in the number of firms listed in the stock market. Both of these scenarios will encourage investors to invest money in the stock market and companies will raise funds from the stock market rather than getting bank loans. Therefore, a more highly developed stock market will reduce demand for banking services.
} 
All of the controlled-for bank-specific, industry-specific, and macroeconomic variables have been identified as having a possible influence on the risk conditions of Chinese commercial banks. However, there was no clear expectation concerning the impact of bank size on bank risk. Large banks can achieve economies of scale and scope, and the resulting cost reduction is helpful in terms of improving bank stability (Berger, 1995). However, due to feeling "too big to fail", large banks may take on higher levels of risk with expectations of higher returns (O'Hara and Shaw, 1990). There was also no clear expectation regarding the impact of diversification on bank risk. On the one hand, diversification puts a bank's eggs in different baskets, which should significantly reduce bank risk; however, empirical studies show that in the US and European banking sectors, diversification has a significant and positive impact on bank risk (Laeven and Levine, 2007; Lepetit et al., 2008). The competition-fragility hypothesis argues that banks can withstand shocks and decrease risk-taking behaviour in a less competitive environment, banks can earn higher profitability through monopoly rents (Allen and Gale, 2004), while the competition-stability hypothesis argues that banks charge higher interest rates in a less competitive banking environment, so that the probability of default on loan repayments increases and bank stability falls (Boyd and De Nicolo, 2005); there were thus no a priori expectations concerning the impact of competition on bank risk.

Finally, in terms of macroeconomic environment, the impact of inflation on bank risk was expected to be significant and negative. Inflation affects the financial system and the real economy adversely, and higher levels of inflation distort decision making, exacerbating information asymmetry and making price levels more volatile (Bush et al., 2014). Jimenez et al. (2013) noted that a higher level of GDP growth increases bank risk, yet Delis and Kouretas (2011) argued that risky asset 
holding increases with growth of GDP. There was thus no a priori expectation regarding the impact of GDP growth on bank risk ${ }^{5}$.

\section{Empirical results}

\subsection{Risk conditions in the Chinese banking industry}

Figures 3a, 3b, 3c, and 3d illustrate the risk conditions of Chinese banks for the period 2003 to 2015. Figure 3a shows that between 2003 and 2008, the credit risk of SOCBs was substantially higher than that of JSCBs and CCBs. However, after 2008, the different ownership types of Chinese commercial banks display few differences with regard to credit risk, though the credit risk of CCBs was higher than that of JSCBs between 2005 and 2010. Figure 3b shows that, in general, the ratio of liquid assets to total assets for SOCBs was lower than that of JSCBs and CCBs. In other words, the SOCBs had the highest liquidity risk. However, liquidity was the highest in CCBs for the period 2005 to 2008. Figure 3c shows the insolvency risk of different bank ownership types over the examined period, suggesting that SOCBs had the lowest insolvency risk; this is mainly attributed to government support and these institutions being considered "too big to fail". In general, the capital level of CCBs increased in many of the years within the period examined, although CCBs showed a slight decrease in other years.

$<<$ Figures 3a-3d---about here>>

\subsection{The impacts of profitability and industry environment on risk in the Chinese banking industry}

${ }^{5}$ Only the controlled variables are discussed in this section, as the impacts of profitability and industry environment on bank risk were discussed in the introduction. 
Before the impacts of profitability and industry environment on the risk-taking behaviours of Chinese commercial banks were investigated, the correlation between independent variables was checked to see whether there were any multicollinearity issues among the variables. The results of this are shown in Table 3, which suggests that the correlation between the variables is not very large. The highest correlations are found between banking sector development and annual GDP growth rate and stock market development and annual GDP growth rate, at 0.69. It is not until a correlation reaches or exceeds 0.8 that a multi-collinearity problem is suspected, as suggested by Kennedy (2008), and thus, in this case, the variables do not suffer from a multicollinearity problem.

$<<$ Table 3---about here >

The results concerning the impacts of profitability and industry environment on risk-taking behaviours by Chinese commercial banks under a fixed-effects model with robust standard errors clustered by bank estimations are reported in Table 4. The results show that higher levels of competition in the Chinese banking industry lead to higher levels of credit risk and insolvency risk. This finding is in line with the competition-fragility hypothesis. In terms of the impact of competition on the liquidity risk and capital risk of Chinese commercial banks, the findings suggest that higher levels of competition in the Chinese banking industry lead to higher levels of both types of risk. This finding is in line with Tan and Anchor (2017a). The significant and positive impact of competition on liquidity risk can be explained by the fact that higher levels of competition induce bank managers to make full use of liquid assets to engage in multiple different types of businesses to obtain higher profits, and the resulting reduction in the level of liquid assets leads to an increase in the level of liquidity risk for Chinese commercial banks. The significant and positive impact of competition on capital risk is mainly attributed to the fact that a higher level of competition in the Chinese banking industry leads to a larger volume of non-performing loans, as 
indicated by the significant and positive impact of competition on credit risk. The Chinese commercial banks then use the capital to write-off these non-performing loans, which precedes a decline in bank capital and further leads to an increase in the level of capital risk.

With regard to the impacts of bank-specific variables on different types of risk taken by Chinese commercial banks, the results indicate that large Chinese commercial banks have higher liquidity risk, as reflected by the significant and negative sign of bank size influence. This is in contrast with the findings of Deng et al. (2013), who examined a sample of bank holding companies, while in agreement with the findings of Singh and Sharma (2016), who looked at the Indian banking industry. In the context of the Chinese banking industry, larger Chinese commercial banks commonly engage in larger volumes of long-term loan businesses, which results in a reduction in bank liquidity and thus increases the level of liquid risk.

The evidence further suggests that Chinese commercial banks with more diversified businesses have higher levels of credit risk. These results are in contrast with the findings of Afzal and Mirza (2012), who found no clear evidence for the impact of bank diversification on credit risk in the Pakistani banking industry. These results can be explained by the fact that Chinese commercial banks with a more diversified businesses need to allocate resources to a broader range of activities, and thus pay less attention to monitoring their loan businesses, leading to an increase in the volume of non-performing loans and a further increase in the level of credit risk.

The main contribution of the current study is to test the impact of profitability on different types of risk in the Chinese banking industry. As reflected in the table, Chinese commercial banks with higher levels of profitability have lower credit risk and insolvency risk, while the impacts on liquidity risk and capital risk are insignificant. This result contradicts the findings of Tan and Floros (2014), which can be mainly attributed to the fact that different econometric techniques 
were used in these studies, with the former using a fixed-effects model with robust standard errors clustered by bank estimations and the latter using a seemingly unrelated regression. The results of the current study can be explained by the fact that higher levels of profitability indicate that the Chinese commercial banks are managed very well and have complete monitoring and management mechanisms in place. These enhanced monitoring systems are helpful in terms of detecting nonperforming loans prior to crisis. The resulting reduction in the volume of non-performing loans leads to a decrease in the level of credit risk and a reduction in insolvency risk.

In terms of the impacts of industry-specific variables on different types of risk in the Chinese banking industry, banking sector development has a significant and positive impact on the level of liquidity risk for Chinese commercial banks, suggesting that a more highly developed banking sector in China leads to an increase in the level of liquidity risk among Chinese commercial banks. As argued by Tan and Floros (2012), a higher level of banking sector development indicates that there is a higher demand for banking services. The resultant increase in the demand for short-term and long-term loans from banks further reduces the amount of cash or liquid assets held by those banks and leads to a reduction in the level of liquidity and an increase in the level of liquidity risk. A more developed banking sector thus leads to a rise in the level of credit risk, as economic sectors rely heavily on the banking sector to obtain credit, and different types of enterprises come with different types of risk; thus, if there is an expansion of credit allocated to all types of companies, the risk level will increase following credit allocation those with lower credit ratings. It is also suggested that a more highly developed banking sector reduces capital risk among Chinese commercial banks, in line with the expectations discussed in the Introduction.

Finally, the results indicate that a higher level of inflation in China leads to a reduction in the level of credit risk among Chinese commercial banks. This result is in contrast with the findings of 
Gunsel (2012) for the Cyprus banking industry, while being in line with the findings of Zribi and Boujelbene (2011) for the Tunisian banking industry. This result can be further explained by the fact that a higher level of inflation indicates an excessive circulation of currency in the economy. To control the volume of currency circulated in the market, banks may reduce the volume of loans made and become more selective in granting credit to various companies. This may lead to a reduction in the number of non-performing loans and thence to a reduction in the level of credit risk.

It is further suggested by the findings that inflation has a significant and negative impact on liquidity risk for Chinese commercial banks, in that a higher level of inflation reduces the liquidity risk. This agrees with the findings of Moussa (2015) from the Tunisian banking industry. The result can be further attributed to the fact that, as discussed earlier, higher levels of inflation reduce the volume of credit granted by banks, causing larger numbers of deposits to be retained in the bank. This excess holding of cash increases the level of liquidity and further leads to a reduction in liquidity risk.

A higher level of inflation is helpful to reducing the capital risk of Chinese commercial banks, as reflected by the significant and positive sign of the related variable. In other words, a higher level of inflation is associated with higher levels of capital buffers among banks. This finding indicates that inflation-induced economic uncertainty stimulates banks to ration credit (Bohachova, 2008). Finally, the results in the table show that a higher level of inflation leads to higher insolvency risk across the Chinese banking industry. This result is in line with the findings of Jabra et al. (2017) from the European banking industry. Higher inflation induces banks to attract deposits and reduces the volume of loans granted. This increase in the volume of deposits increases the bank's interest expenses, while the reduction in the volume of loans decreases interest income; this growing 
mismatch between expenses and incomes will further lead to an increase in the possibility that the banks will be unable to meet their obligations when they become due, leading to an increase in the level of insolvency risk.

<<Table 4---about here >>

To check the robustness of the results, several alternative tests were performed. Thus, as well as using the Lerner index as a competition indicator, this study also used the Herfindahl-Hirschman index as a measurement of bank competition. Furthermore, the robustness of the results was crosschecked by using different indicators for credit risk and liquidity risk. As well as measuring the credit risk as the ratio of non-performing loans to total loans, the study employed the ratio of loan loss provisions to total loans as an alternate measurement of credit risk, and instead of using the ratio of liquid assets to total assets as the only indicator of liquidity risk, the current study also assessed the level of liquidity risk by examining the ratio of deposits to total assets. The results, using the Herfindahl-Hirschman index as the competition indicator are reported in Table 5, and the results using the alternate credit risk and liquidity risk indicators are reported in Table 6. Overall, as reflected by these two tables in comparison to the original estimation in Table 4, the following findings were confirmed:

1) higher levels of competition in the Chinese banking industry lead to higher levels of credit risk, liquidity risk, capital risk, and insolvency risk;

2) Chinese commercial banks of larger size in terms of assets have a higher levels of liquidity risk;

3) Chinese commercial banks with more diversified businesses have a higher level of credit risk; 4) the profitability of Chinese commercial banks is significantly and negative related to the levels of credit risk and insolvency risk; 
5) there is a significant and positive impact from banking sector development on liquidity risk and credit risk, though this has a negative impact on capital risk;

6) inflation is significantly and negatively related to credit risk, liquidity risk, and capital risk, but positively related to insolvency risk.

$<<$ Table 5---about here >>

$<<$ Table 6---about here>>

\section{Additional Robustness Checks}

In addition to the robustness checks noted above, many additional robustness tests were implemented to cross-check the accuracy of the results. Several different econometric techniques were applied to examine the impacts of profitability and industry environment on the risk-taking behaviours of Chinese commercial banks. These were the generalized method of moments system estimator, following Tan and Anchor (2017a) and the three-stage least square estimator following Tan and Floros (2013b). In addition to these alternative econometric techniques, an alternative indicator was also used to measure insolvency risk. While the study used the Z-score as the main indicator of insolvency risk, some researchers argue that the inherent stability of a bank is not necessarily reflected by the Z-score, and that the deviation from the bank's current stability and its maximum stability should be considered in order to more accurately measure the level of insolvency risk (Tabak et al., 2012). Thus, stability inefficiency was also examined as an alternative insolvency risk indicator and the results compared with the findings derived from the Z-score. Finally, alternative profitability indicators were also employed. After using ROA as a profitability indicator, the study cross-checked the robustness of the results by also using Return 
on Equity (ROE) and Net Interest Margin (NIM), which are widely used in the banking literature to measure bank profitability. ${ }^{6}$

\section{Conclusion}

The current study contributes to the banking literature, and particularly that segment focused on China, by investigating the impacts of profitability and industry environment on different types of risk in the Chinese banking industry for the period 2003 to 2015 . This study is the first investigating the impacts of banking sector development and stock market development on different types of risk in the Chinese banking industry.

The findings of the current paper suggest that higher levels of competition in the Chinese banking industry lead to higher levels of credit risk, liquidity risk, capital risk, and insolvency risk among Chinese commercial banks. This finding is in line with the competition-fragility hypothesis found within extant empirical banking literature. Further, it is suggested that Chinese commercial banks with higher levels of profitability experience lower credit risk and insolvency risk, while large Chinese commercial banks have a higher level of liquidity risk. Chinese commercial banks with more diversified businesses are also found to have higher volumes of non-performing loans. Not only were bank-specific variables found to have a significant influence on the risk-taking behaviours of Chinese commercial banks but also the more developed banking sector was found to increase liquidity and credit risks while decreasing capital risk among Chinese commercial banks. Finally, the results suggest that Chinese commercial banks have a lower level of credit risk,

\footnotetext{
${ }^{6}$ The results from all of the additional robustness checks are quantitatively similar to those from the original tests. This supports the assertion that the findings from the original estimations are accurate. The results of these additional tests are thus not reported, to prevent repetition; however, they are available upon request from the corresponding author.
} 
liquidity risk, and capital risk during periods of high inflation, while, in contrast, insolvency risk is high during such periods.

The findings from this work have important implications for the Chinese government and banking regulatory authorities:

1) In order to enhance banking stability in China, relevant measures should be taken by the Chinese government or banking regulatory authority to reduce the level of competition;

2) Large Chinese commercial banks should be encouraged to decrease their volumes of loans granted to long-term projects. This will increase their liquidity levels, further reducing the level of liquidity risk;

3) Business diversification should be considered more carefully, as most banks will benefit from economies of scope. However, this can lead to a higher level of credit risk;

4) Both bank operations and cost management should be further improved, as the former is strongly positively related to bank revenue, while the cost reductions derived from the latter can increase bank profitability and further enhance bank stability.

Future studies might usefully investigate this issue in the context of the banking sector of other Asian or European countries to test whether the findings reported in this paper are generalisable to alternative institutional settings. 


\section{Appendix. Measurement of bank competition in China}

In recent years, several research articles have used different methods to investigate competitive conditions in the banking industry, including the k-bank concentration ratio, HerfindahlHirschman index, Panzar-Rosse $\mathrm{H}$ statistic, Lerner index, and Boone indicator, as indicated in the literature review.

Although some researchers have used the Panzar-Rosse $\mathrm{H}$ statistic to investigate competition in the banking sector, this measure suffers from two major drawbacks. Leuvensteijn et al. (2011) argued that the $\mathrm{H}$ statistic is based on a static model, which means that no predictions based on the H-statistic are possible. Furthermore, Claessens and Laeven (2004) argued that, because of market entries and exits, it cannot fulfil the requirement of overall market equilibrium, which further limits the interpretation of such analyses. The Boone indicator similarly suffers from two disadvantages. Tabak et al. (2012) argued that the Boone indicator assumes, possibly incorrectly, that banks pass part of their efficiency gains on to consumers. This indicator suffers from idiosyncratic variation known as uncertainty.

The current study uses the Lerner index to measure competition in the Chinese banking industry for two main reasons:

1) The Lerner index provides the market power of each bank in a specific year and matches this with its determinants, which are the bank-level variables for each year;

2) The Lerner index can estimate the competitive conditions (market power) for all three different ownership types of Chinese banks.

Other research articles have also used this indicator to measure competition in the banking sector, however (Khan et al., 2017; Hryckiewicz and Kozlowski, 2018). The Lerner index is defined as 
the difference between a bank's price and the marginal cost, divided by the price. The index value thus ranges from a maximum of 1 to a minimum of zero, with higher numbers indicating greater market power and hence less competition. The Lerner index represents the extent to which a particular bank has the market power to set its prices above its marginal costs. The average price of bank production (proxied by total assets), calculated as the ratio of total revenue to total assets, measures the price. This measurement follows Fernandez de Guevara et al. (2005) and Carbo et al. (2009). A translog cost function with three outputs and two input prices can thus measure the marginal cost. This cost function has the form

$L N\left(\frac{C}{W_{2}}\right)_{i t}=\delta_{0}+\sum_{j} \delta_{j} L N Y_{j i t}+\frac{1}{2} \sum_{j} \sum_{k} \delta_{j k} L N Y_{j i t} L N Y_{k i t}+\beta_{1} L N\left(\frac{W_{1}}{W_{2}}\right)_{i t}+\frac{1}{2} \beta_{11} L N\left(\frac{W_{1}}{W_{2}}\right)_{i t} L N\left(\frac{W_{1}}{W_{2}}\right)_{i t}+\sum_{j} \theta_{j} L N Y_{j i t} L N\left(\frac{W_{1}}{W_{2}}\right)_{i t}+\varepsilon_{i t}$

\section{(A.1)}

where $\mathrm{C}$ represents the total cost of a bank; Y represents four outputs, which are whole loans, total deposits, non-interest income, and securities; and W stands for two input prices, W1 being the price of funds as measured by the ratio of interest expenses to total deposits, and W2 representing the price of capital as measured by the ratio of non-interest expenses to fixed assets. These two input prices are considered as non-interest expenses also include labour costs (Hasan and Marton, 2003). Thus, the price of capital must consider the factors relating to the price of physical capital as well as the price of human capital. Linear homogeneity is ensured by normalising both the dependent variable and W1 with respect to the other input price, W2. The marginal cost of loans can thus be obtained by taking the first derivative of the dependent variable in equation (A.1) as follows:

$$
M C_{i l t}=\left(\frac{C_{i t} / W_{2}}{Y_{i l t}}\right)\left(\delta_{j=l}+2 \delta_{l l} L N Y_{i l t}+\sum_{k-1 \ldots k, k \neq l} \delta_{l k} L N Y_{i k t}+\theta_{l} L N\left(\frac{W_{1}}{W_{2}}\right)\right)
$$




\section{References}

Afzal, A. and Mirza, N. (2012). Size, diversification and risk: preliminary evidence from commercial banks in Pakistan. Pakistan Journal of Commerce Social Sciences 6, 282-296.

Allen, F. and Gale, D. (2004) Competition and financial stability, Journal of Money, Credit and Banking 36, 433-480.

Basel Committee on Banking Supervision (2000). Principles for the Management of Credit Risk. Banks for International Settlements, Basel, Switzerland.

Beck, T., Demirguc-Kunt, A. and Merrouche, O. (2013). Islamic vs. conventional banking: business model, efficiency and stability. Journal of Banking and Finance 37, 433-447.

Bohachova, O. (2008). The impact of macroeconomic factors on risks in the banking sector: a cross-country empirical evidence. IAW discussion paper, No. 44.

Boyd, J. and De Nicolo, G. (2005) The theory of bank risk-taking revisited, Journal of Finance 60, 1329-1343.

Brissimis, S. M., Delis, M.D. and Papanilolaou, N. I. (2008). Exploring the nexus between banking sector reform and performance: evidence from newly acceded EU countries. Journal of Banking and Finance 32, 2674-2683.

Broll, U., Welzel, P., \& Wong, K. P. (2018). Ambiguity preferences, risk taking and the banking firm. Eurasian Economic Review, 8(3), 343-353.

Bush, C. M., Eickmeier, S. and Prieto, E. (2014). Macroeconomic factors and microlevel bank behaviour. Journal of Money, Credit and Banking 46, 715-751. 
Carbo, S., Humphrey, D., Maudos, J. and Monlynuex, P. (2009). Cross country comparisons of competition and pricing power in European banking. Journal of International Money and Finance $28,115-134$.

Claessens, S. and Laeven, L. (2004). What drives bank competition? Some international evidence. Journal of Money, Credit and Banking 36, 563-583.

Delis, M. D. and Kouretas, G. P. (2011). Interest rates and bank risk-taking. Journal of Banking and Finance 35, 840-855.

Demsetz, R. S., Saindenberg, M. R. and Strahan, P. E. (1996). Banks with something to lose: the disciplinary role of franchise value. Federal Reserve Bank of New York Economic Policy Review $2,1-14$.

Deng, S., Elyasiani, E. and Jia, J. (2013) Institutional Ownership, Diversification and Riskiness of Bank Holding Companies, The Financial Review 48, 385-415.

Fang, J., Lau, C.K., Lu, Z., Tan, Y. and Zhang, H. (2019). Bank performance in China: A perspective from bank efficiency, risk-taking and market competition. Pacific-Basin Finance Journal 56, 290-309.

Fernandez de Guevara, J., Maudos, J. and Perez, F. (2005). Market power in European banking sectors. Journal of Financial Services Research 27, 109-137.

Fiordelisi, F., Marques-Ibanez, D. and Molyneux, P. (2011). Efficiency and risk in European Banking. Journal of Banking and Finance 35, 1315-1326. 
Francis, W. B. and Osborne, M. (2012). Capital requirements and bank behaviour in the UK: are there lessons for international capital standards. Journal of Banking and Finance 36, 803-816.

Fu, X. (2009). Competition in Chinese commercial banking. Banking and Finance Review, 1, 116.

Fu, X., Lin, Y. and Molynuex, P. (2014). Bank competition and financial stability in Asia Pacific. Journal of Banking and Finance 38, 64-77.

Fungacova, Z., Pessarossi, P. and Weill, L. (2013). Is bank competition detrimental to efficiency? Evidence from China. China Economic Review 27, 121-134.

Garcia-Herrero, A., Gavila, S. and Santabarbara, D. (2009). What explains the low profitability of Chinese banks? Journal of Banking and Finance 33, 2080-2092.

Goddard, J., Moluneux, P. and Wilson, J. O.S. (2009). The financial crisis in Europe: evolution, policy responses, and lessons for the future. Journal of Financial Regulation and Compliance 17, 362-380.

Gunsel, N. (2012). Micro and Macro determinants of bank fragility in North Cyprus economy. African Journal of Business Management 3, 1323-1329.

Hasan, I., and Marton, K. (2003). Development and efficiency of the banking sector in a transitional economy: Hungarian experience. Journal of Banking and Finance 27, 2249-2271.

Hellmann, T., Murdock, K. and Stiglitz, J. E. (2000). Liberalization, moral hazard in banking and prudential regulation: are capital requirements enough? American Economic Review 90, 147-165. 
Hryckiewicz, A., and Kozlowski, L. (2018). A horserace or boost in market power? Banking sector competition after foreign bank exists? International Review of Economics and Finance, in press.

Hu, T. and Xie, C. (2016). Competition, Innovation, Risk-taking, and Profitability in the Chinese banking sector: an empirical analysis based on structural equation modeling. Discrete Dynamics in Nature and Society 2016, 1-10.

Iannotta, G., Nocera, G. and Sironi, A. (2007). Ownership structure, risk and performance in the European banking industry. Journal of Banking and Finance 31, 2127-2149.

Jabra, W.B., Mighri, Z. and Mansouri, F. (2017). Determinants of European bank risk during financial crisis. Cogent Economics and Finance 5, 1-20.

Jimenez, G., Lopez, J. A. and Saurina, J. (2013). How does competition affect bank risk-taking? Journal of Financial Stability 9, 185-195.

Kennedy, P. (2008). A guide to econometrics. Malden, MA: Blackwell publishing.

Khan, H. H., Kutan, A. M., Ahmad, R. B. and Gee, C. K. (2017). Does higher bank concentration reduce the level of competition in the banking industry? Further evidence from South East Asian Economies. International Review of Economics and Finance 52, 92-106.

Laeven, L. and Levine, R. (2007). Is there a diversification discount in financial conglomerates? Journal of Financial Economics 85, 331-367.

Lepetit, L., Nys, E., Rous, P. and Tarazi, A. (2008). Bank income structure and risk: an empirical analysis of European banks. Journal of Banking and Finance 32, 1452-1467. 
Leuvensteijn, M.V., Bikker, J.A., van Rixtel, A. and Sorensen, C. K. (2011). A new approach to measuring competition in the loan markets of the euro area. Applied Economics 43, 3155-3167.

Liu, H., Molyneux, P. and Nguyen, L. H. (2012). Competition and risk in south east Asian commercial banking. Applied Economics 44, 3627-3644.

Liu, H., Molyneux, P. and Wilson, J.O.S. (2013) Competition and stability in European banking: a regional analysis, The Manchester School 81, 176-201.

Liu, H. and Wilson, J.O.S. (2013) Competition and risk in Japanese banking, European Journal of Finance 19, 1-18.

Liu, Y. (2017). Regulation, Competition and Bank risk: Evidence from China. Asian Business Research 2, 42-49.

Kleff, V. and Weber, M. (2008). How do banks determine capital? Evidence from Germany. German Economic Review 9, 354-372.

Konara, P., Tan, Y. and Johnes, J. (2019). FDI and heterogeneity in bank efficiency: evidence from emerging markets. Research in International Business and Finance 49, 100-113.

Masood, O. and Sergi, B. S. (2011). China's banking system, market structure, and competitive conditions. Frontiers of Economics in China 6, 22-35.

Moussa, M. A. B. (2015). The determinants of bank liquidity: the case of Tunisia. International Journal of Economics and Financial Issues 5, 249-259. 
O'Hara, M. and Shaw, W. (1990). Deposit insurance and wealth effects: the benefit of being too big to fail. Journal of Finance 45, 1587-1600.

Osborne, M., Fuertes, A. and Milne, A. (2017). In good times and in bad: Bank capital ratios and lending rates. International Review of Financial Analysis 51, 102-112.

Park, K. H. (2013). Testing for competition in the South Korean and Chinese commercial banking markets. Asia-Pacific Journal of Financial Studies 42, 56-75.

Singh, A., and Sharma, A. K. (2016). An empirical analysis of macroeconomic and bank-specific factors affecting liquidity of Indian banks. Future Business Journal 2, 40-53.

Tabak, B.M., Fazio, D.M. and Cajueiro, D.O. (2012) The relationship between banking market competition and risk-taking: Do size and capitalization matter? Journal of Banking and Finance $36,3366-3381$.

Tan, Y. and Floros, C. (2012). Bank profitability and inflation: the case of China. Journal of Economic Studies 39, 675-696.

Tan, Y. (2013). Essays on the analysis of performance and competitive condition in the Chinese banking industry. Ph.D. thesis, University of Portsmouth, UK.

Tan, Y. and Floros, C. (2013a) Market power, stability and performance in the Chinese banking industry, Economic Issues 18, 65-89.

Tan, Y. and Floros, C. (2013b) Risk, capital and efficiency in Chinese banking, Journal of International Financial Markets, Institutions and Money 26, 378-393. 
Tan, Y. (2014). Performance, risk and competition in the Chinese banking industry. UK, Oxford: Chandos Publishing.

Tan, Y. and Floros, C. (2014) Risk, profitability and competition: evidence from the Chinese banking, Journal of Developing Areas 48, 303-319.

Tan, Y. (2016). Investigating the Performance of Chinese Banks: Efficiency and Risk Features. London: Palgrave Macmillan.

Tan, Y. and Anchor, J. (2017a). Does competition only impact on insolvency risk? New evidence from the Chinese banking industry. International Journal of Managerial Finance, 13, 332-354.

Tan, Y. and Anchor, J. (2017b). The impacts of risk-taking behaviour and competition on technical efficiency: evidence from the Chinese banking industry. Research in International Business and Finance, 41, 90-104.

Tan, Y., Floros, C. and Anchor, J. (2017). The profitability of Chinese banks: impacts of risk, competition and efficiency. Review of Accounting and Finance, 16, 86-105.

Tan, Y. (2017). The impacts of competition and shadow banking on profitability: evidence from the Chinese banking industry. North American Journal of Economics and Finance, 42, 89-106.

Tan, Y. and Floros, C. (2018). Risk, competition and efficiency in banking: Evidence from China. Global Finance Journal 35, 223-236. 
Tan, Y. (2019). Competition and Profitability in the Chinese Banking Industry: New Evidence from Different Ownership Types. Journal of Industry, Competition and Trade, https://doi.org/10.1007/s10842-019-00305-4

Tan, Y. and Anchor, J. (2016). Stability and Profitability in the Chinese Banking Industry: evidence from an auto-regressive-distributed linear specification. Investment Management and Financial Innovations 13, 120-129.

Yuan, Y. (2006). The state of competition of the Chinese banking industry. Journal of Asian Economics 17, 519-534.

Zribi, N. and Boujelbene, Y. (2011). The factors influencing bank credit risk: The case of Tunisia. Journal of Accounting and Taxation 3, 70-78. 
Figure 1. The relationship between credit risk and stock market development

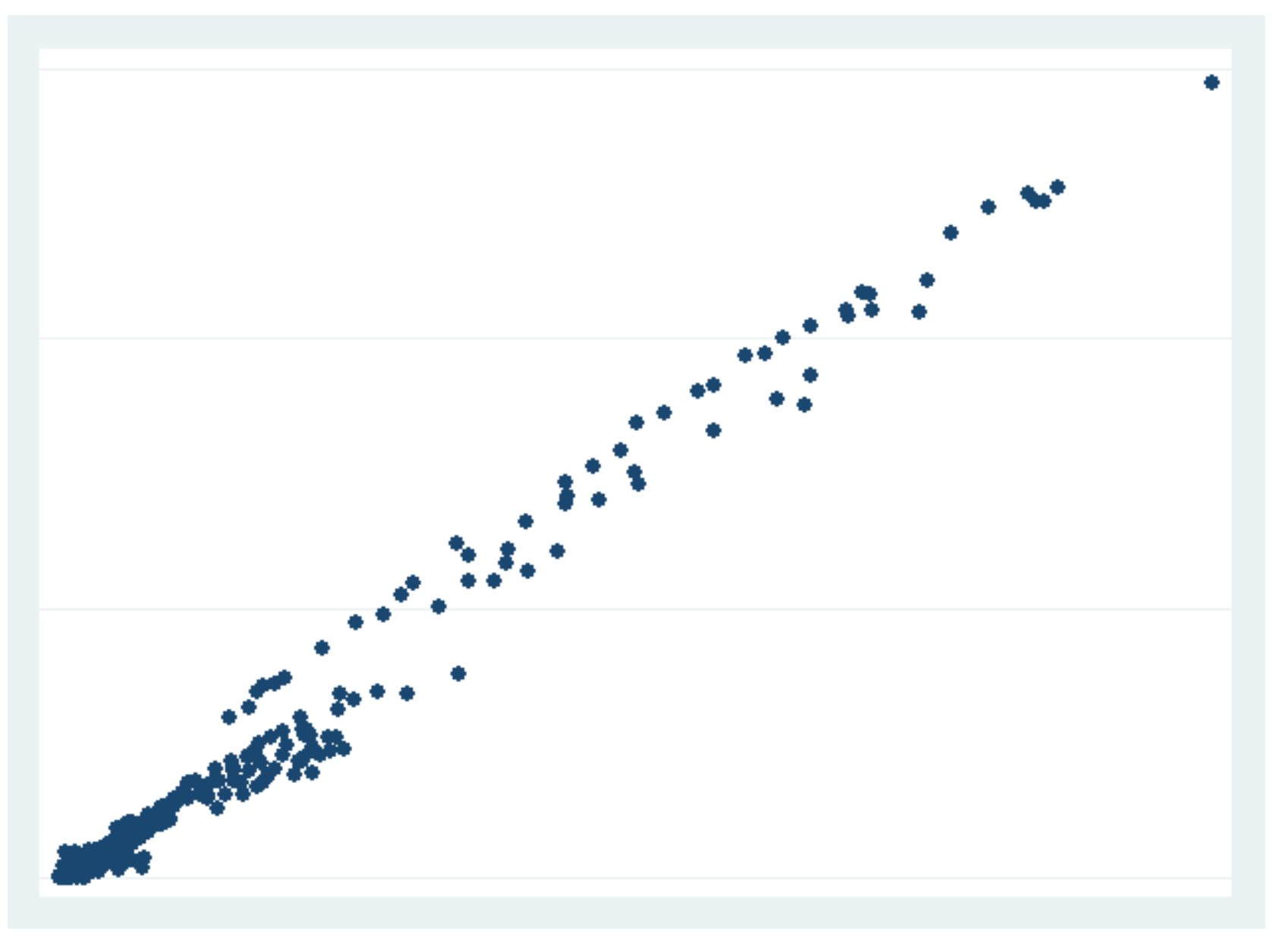


Figure 2 Bank size, bank profitability, bank diversification across different bank ownership types over the period

Figure 2a. Bank size

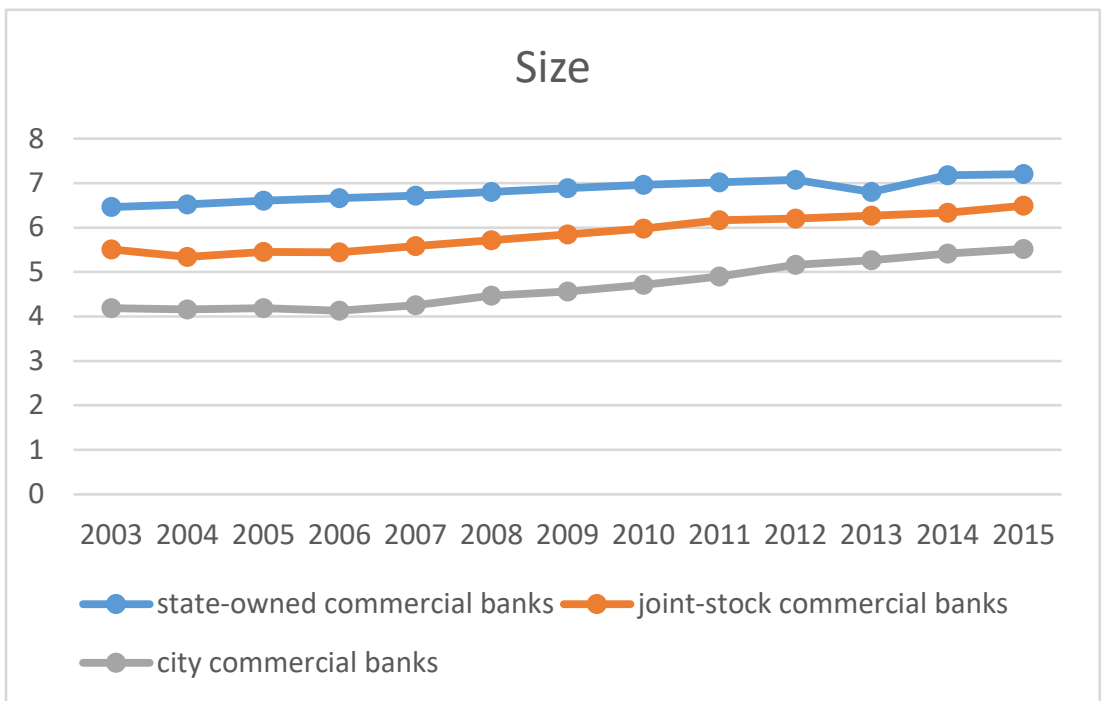

Figure 2c. Bank diversification

bank diversification

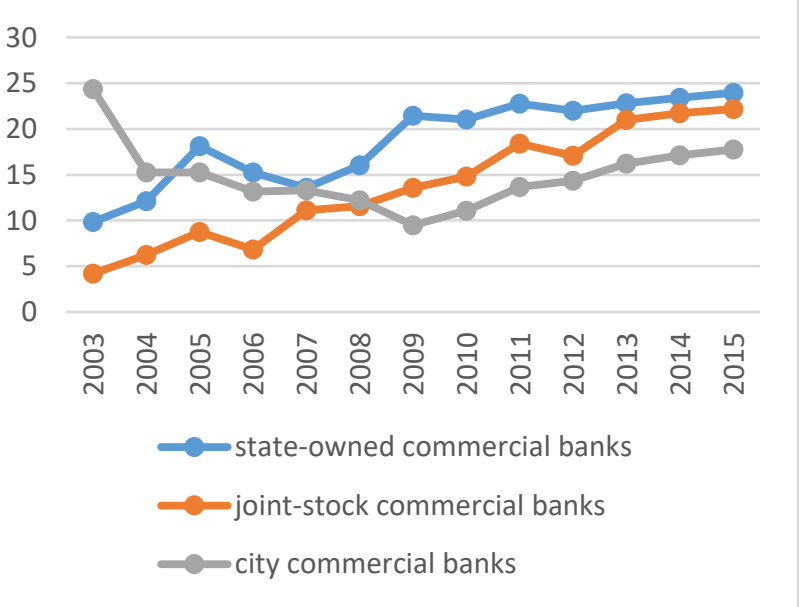

Figure 2b. Bank profitability

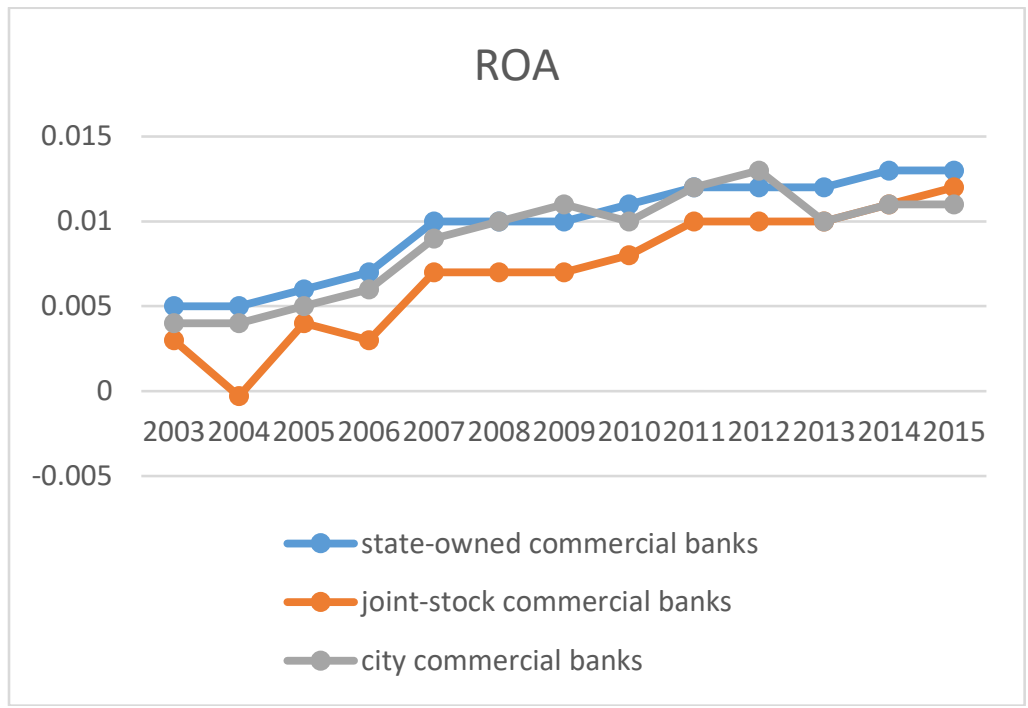


Figure 3 Risk conditions in the Chinese banking industry: 2003-2015

Figure 3a Credit risk in the Chinese banking industry

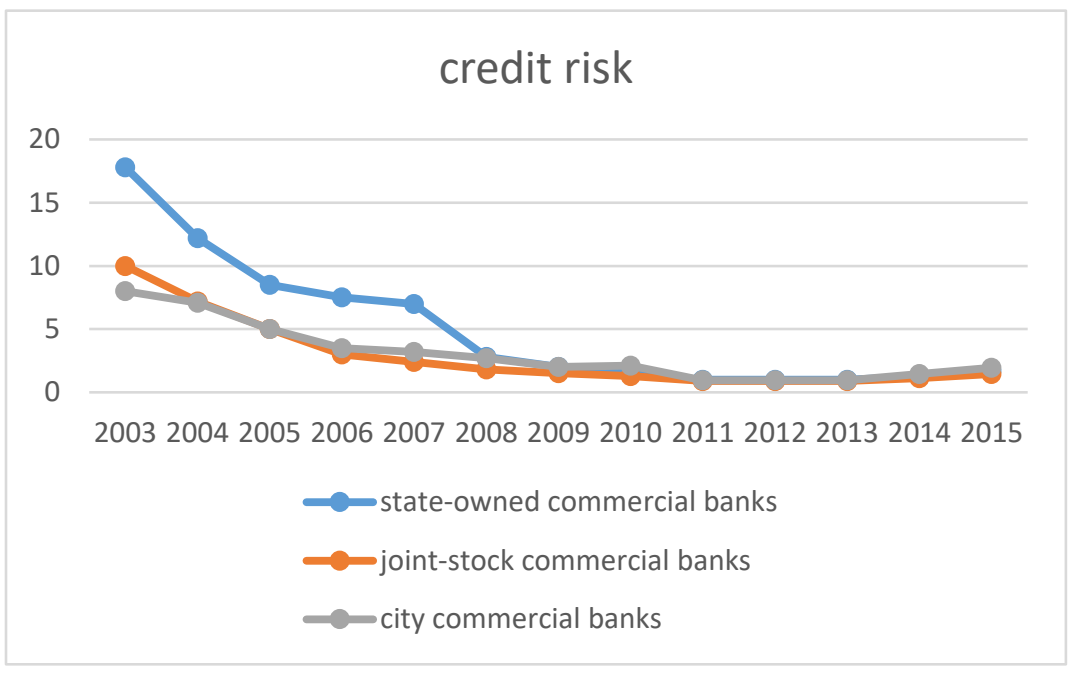

Figure 3c Insolvency risk in the Chinese banking industry

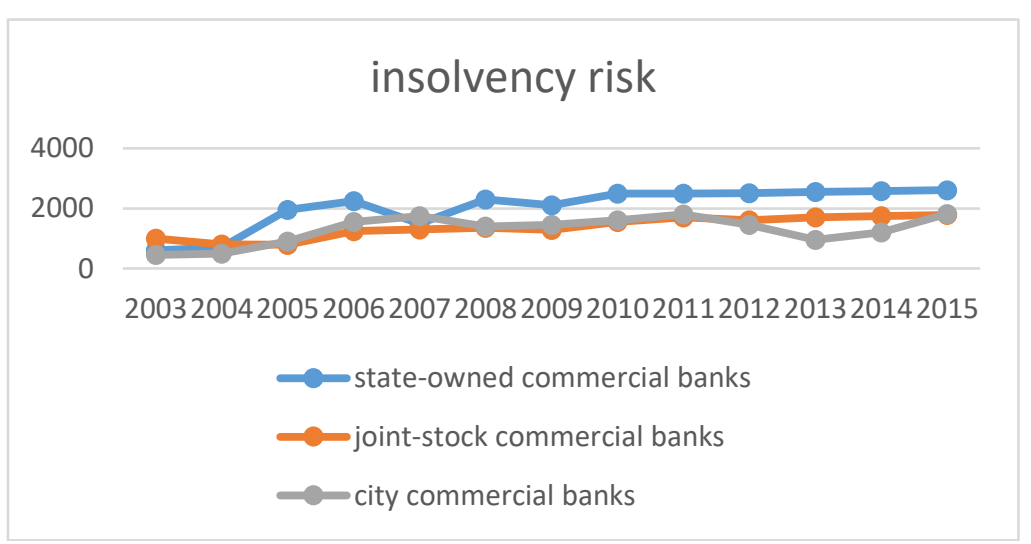

Figure 3b Liquidity risk in the Chinese banking industry

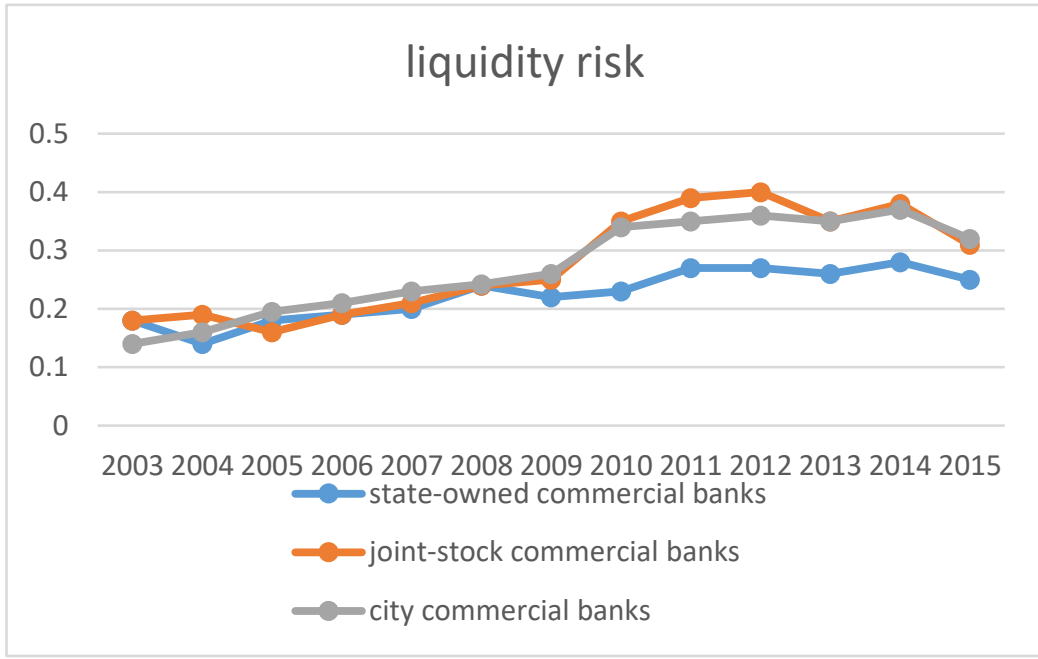

Figure 3d Capital risk in the Chinese banking industry

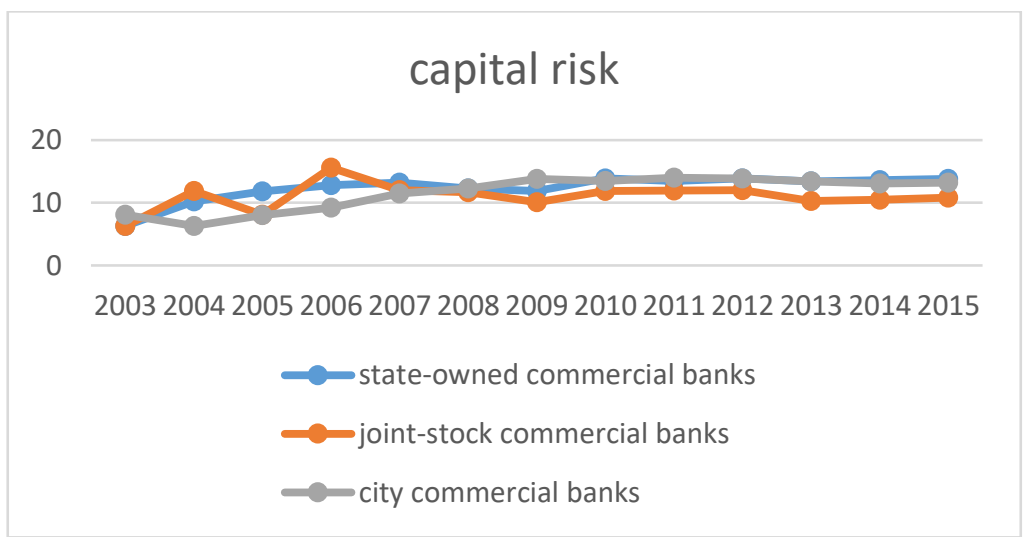


Table 1 Description of the variables used in the study

\begin{tabular}{|c|c|c|c|}
\hline Variables & Indicator & Definition & Data source \\
\hline \multirow[t]{4}{*}{ Risk } & Credit risk & $\begin{array}{l}\text { The ratio of non- } \\
\text { performing loans to total } \\
\text { loans }\end{array}$ & Bankscope \\
\hline & Liquidity risk & $\begin{array}{l}\text { The ratio of liquid assets to } \\
\text { total assets }\end{array}$ & Bankscope \\
\hline & Capital risk & $\begin{array}{l}\text { Total regulatory capital } \\
\text { ratio }\end{array}$ & Bankscope \\
\hline & Insolvency risk & Z-score & Bankscope \\
\hline \multicolumn{4}{|l|}{ Bank-specific variables } \\
\hline Bank size & Size & $\begin{array}{l}\text { Natural logarithm of total } \\
\text { assets }\end{array}$ & Bankscope \\
\hline Bank diversification & Diverse & $\begin{array}{l}\text { The ratio of non-interest } \\
\text { income to gross revenue }\end{array}$ & Bankscope \\
\hline Bank profitability & ROA & Return on Assets & Bankscope \\
\hline \multicolumn{4}{|l|}{ Industry-specific variables } \\
\hline Banking sector development & BSD & $\begin{array}{l}\text { The ratio of domestic } \\
\text { credits to the private sector } \\
\text { by banks to GDP }\end{array}$ & World Bank \\
\hline Stock market development & SMD & $\begin{array}{l}\text { The ratio of the market } \\
\text { capitalization of listed } \\
\text { companies to GDP }\end{array}$ & $\begin{array}{l}\text { CBRC and World } \\
\text { Bank }\end{array}$ \\
\hline Competition & Lerner index & See appendix & Bankscope \\
\hline \multicolumn{4}{|l|}{ Macroeconomic variables } \\
\hline Inflation & INF & Annual inflation rate & World Bank \\
\hline GDP growth & GDPG & $\begin{array}{l}\text { The annual GDP growth } \\
\text { rate }\end{array}$ & World Bank \\
\hline
\end{tabular}


Table 2 Descriptive statistics of the variables used in the current study

\begin{tabular}{|c|c|c|c|c|c|}
\hline Variables & Observations & Mean & S.D & Min & Max \\
\hline Credit risk & 1088 & 2.78 & 4.48 & 0 & 13.86 \\
\hline Liquidity risk & 1018 & 0.27 & 0.11 & 0.02 & 0.67 \\
\hline Capital risk & 1010 & 11.91 & 4.7 & 0.62 & 24.04 \\
\hline Insolvency risk & 1010 & 0.33 & 0.21 & 0.025 & 0.789 \\
\hline \multicolumn{6}{|l|}{$\begin{array}{l}\text { Bank-specific } \\
\text { variables }\end{array}$} \\
\hline Bank profitability & 1118 & 0.009 & 0.007 & -0.04 & 0.106 \\
\hline Bank size & 1092 & 4.9 & 0.992 & 0.71 & 8.51 \\
\hline $\begin{array}{l}\text { Bank } \\
\text { diversification }\end{array}$ & 1000 & 13.98 & 13.31 & -12.94 & 79.4 \\
\hline \multicolumn{6}{|l|}{$\begin{array}{l}\text { Industry-specific } \\
\text { variables }\end{array}$} \\
\hline $\begin{array}{l}\text { Banking sector } \\
\text { development }\end{array}$ & 1300 & 123.41 & 14.38 & 102.004 & 153.2 \\
\hline $\begin{array}{l}\text { Stock market } \\
\text { development }\end{array}$ & 1300 & 71.2 & 43.49 & 31.9 & 184.1 \\
\hline $\begin{array}{l}\text { Bank competition } \\
\text { (Lerner index) }\end{array}$ & 1018 & 0.22 & 5.1 & 0.04 & 0.38 \\
\hline $\begin{array}{l}\text { Bank competition } \\
\text { (Herfindahl- } \\
\text { Hirschman index) }\end{array}$ & 1300 & 0.022 & 0.01 & 0.017 & 0.038 \\
\hline \multicolumn{6}{|l|}{$\begin{array}{l}\text { Macroeconomics } \\
\text { variables }\end{array}$} \\
\hline Inflation & 1300 & 2.86 & 1.92 & -0.77 & 5.86 \\
\hline GDP growth rate & 1300 & 10.19 & 1.87 & 7.7 & 14.2 \\
\hline
\end{tabular}

Notes: all the variables in the above table are in the format of percentage, while to calculate the percentage, all the variables involved in the calculation are measured by million RMB. Inflation and GDP growth rates are the statistics directly from World Bank. 
Table 3Correlation matrix

\begin{tabular}{|c|c|c|c|c|c|c|c|c|}
\hline & $\begin{array}{l}\text { Bank } \\
\text { competition }\end{array}$ & Bank size & $\begin{array}{l}\text { Bank } \\
\text { diversification }\end{array}$ & $\begin{array}{l}\text { Bank } \\
\text { profitability }\end{array}$ & $\begin{array}{l}\text { Banking } \\
\text { sector } \\
\text { development }\end{array}$ & $\begin{array}{l}\text { Stock } \\
\text { market } \\
\text { development }\end{array}$ & $\begin{array}{l}\text { Annual } \\
\text { inflation } \\
\text { rate }\end{array}$ & $\begin{array}{l}\text { The annual } \\
\text { GDP } \\
\text { growth rate }\end{array}$ \\
\hline $\begin{array}{l}\text { Bank } \\
\text { competition }\end{array}$ & 1 & & & & & & & \\
\hline Bank size & 0.17 & 1 & & & & & & \\
\hline $\begin{array}{l}\text { Bank } \\
\text { diversification }\end{array}$ & -0.22 & 0.04 & 1 & & & & & \\
\hline $\begin{array}{l}\text { Bank } \\
\text { profitability }\end{array}$ & 0.29 & 0.06 & -0.01 & 1 & & & & \\
\hline $\begin{array}{l}\text { Banking } \\
\text { sector } \\
\text { development }\end{array}$ & 0.21 & 0.28 & -0.002 & 0.33 & 1 & & & \\
\hline $\begin{array}{l}\text { Stock market } \\
\text { development }\end{array}$ & 0.06 & -0.15 & -0.06 & 0.03 & -0.3 & 1 & & \\
\hline $\begin{array}{l}\text { Annual } \\
\text { inflation rate }\end{array}$ & 0.07 & 0.01 & -0.007 & 0.09 & -0.13 & 0.16 & 1 & \\
\hline $\begin{array}{l}\text { Annual GDP } \\
\text { growth rate }\end{array}$ & -0.1 & -0.26 & -0.02 & -0.18 & -0.69 & 0.69 & 0.09 & 1 \\
\hline
\end{tabular}


Table 4 The impacts of profitability and competition on bank risk (fixed-effects estimation)- robust standard errors clustered by banks

\begin{tabular}{|c|c|c|c|c|c|c|c|c|}
\hline & \multicolumn{2}{|c|}{$\begin{array}{c}\text { Dependent variable= } \\
\text { credit risk }\end{array}$} & \multicolumn{2}{|c|}{$\begin{array}{c}\text { Dependent variable= } \\
\text { liquidity risk }\end{array}$} & \multicolumn{2}{|c|}{$\begin{array}{c}\text { Dependent variables= } \\
\text { capital risk }\end{array}$} & \multicolumn{2}{|c|}{$\begin{array}{c}\text { Dependent variable= } \\
\text { insolvency risk }\end{array}$} \\
\hline Independent variables & Coefficient & T-stat & Coefficient & T-stat & Coefficient & T-stat & Coefficient & T-stat \\
\hline \multicolumn{9}{|l|}{ competition variables } \\
\hline $\begin{array}{c}\text { competition (Lerner } \\
\text { index) }\end{array}$ & $-2.21 * *$ & -2.28 & $1.01 * *$ & 2.45 & $3.73 *$ & 1.93 & $5.13 * * *$ & 6.68 \\
\hline \multicolumn{9}{|l|}{$\begin{array}{c}\text { Other controlled } \\
\text { variables }\end{array}$} \\
\hline Bank size & 0.07 & 0.86 & $-0.05 * * *$ & -3.97 & 0.19 & 0.65 & 0.31 & 0.17 \\
\hline Bank diversification & $0.04 * *$ & 2.36 & 0.06 & 0.51 & 0.43 & 0.33 & 0.79 & 0.38 \\
\hline Bank profitability & $-13.41 * * *$ & -4.51 & 0.24 & 0.33 & 0.55 & 0.54 & $0.90 * *$ & 2.87 \\
\hline $\begin{array}{c}\text { Banking sector } \\
\text { development }\end{array}$ & $2.66 * *$ & 2.48 & $-0.21 * * *$ & -8.78 & $0.88 * *$ & 2.88 & 0.44 & 0.48 \\
\hline $\begin{array}{l}\text { Stock market } \\
\text { development }\end{array}$ & 0.01 & 0.09 & 0.06 & 0.12 & 0.51 & 0.13 & 0.15 & 1.12 \\
\hline inflation & $-0.36^{* *}$ & -2.34 & $0.02 * *$ & 2.62 & $0.18 * * *$ & 3.83 & $-0.89 * * *$ & -4.87 \\
\hline GDP growth rate & 0.23 & 1.17 & 0.19 & 0.32 & 0.77 & 0.12 & 0.15 & 0.51 \\
\hline Constant & $0.05 * * *$ & 13.24 & $0.06 * * *$ & 9.73 & $0.01 * * *$ & 10.41 & $0.24 * * *$ & 6.32 \\
\hline Observations & \multicolumn{2}{|c|}{1100} & \multicolumn{2}{|c|}{1018} & \multicolumn{2}{|c|}{1011} & \multicolumn{2}{|c|}{1010} \\
\hline R-Squared (Within) & \multicolumn{2}{|c|}{0.168} & \multicolumn{2}{|c|}{0.173} & \multicolumn{2}{|c|}{0.198} & \multicolumn{2}{|c|}{0.212} \\
\hline Probability $>F$ & \multicolumn{2}{|c|}{$13.55 * * *$} & \multicolumn{2}{|c|}{$14.61 * * *$} & \multicolumn{2}{|c|}{$13.99 * * *$} & \multicolumn{2}{|c|}{$15.13 * * *$} \\
\hline
\end{tabular}

Note: $*, * *$ and $* *$ denote significance at $10 \%, 5 \%$ and $1 \%$ levels, respectively. 
Table 5 The impacts of profitability and competition on bank risk (fixed-effects estimation with Herfindahl-Hirschman index as competition indicator)- - robust standard errors clustered by banks

\begin{tabular}{|c|c|c|c|c|c|c|c|c|}
\hline & \multicolumn{2}{|c|}{$\begin{array}{c}\text { Dependent variable }= \\
\text { credit risk }\end{array}$} & \multicolumn{2}{|c|}{$\begin{array}{c}\text { Dependent variable= } \\
\text { liquidity risk }\end{array}$} & \multicolumn{2}{|c|}{$\begin{array}{c}\text { Dependent variables }= \\
\text { capital risk }\end{array}$} & \multicolumn{2}{|c|}{$\begin{array}{l}\text { Dependent variable= } \\
\text { insolvency risk }\end{array}$} \\
\hline Independent variables & Coefficient & T-stat & Coefficient & T-stat & Coefficient & T-stat & Coefficient & T-stat \\
\hline \multicolumn{9}{|l|}{ competition variables } \\
\hline $\begin{array}{c}\text { competition (Herfindahl- } \\
\text { Hirschman index) }\end{array}$ & $-2.15 * * *$ & -6.73 & $1.14 * * *$ & 10.51 & $4.46^{* * *}$ & 2.79 & $5.39 * * *$ & 7.82 \\
\hline \multicolumn{9}{|l|}{$\begin{array}{l}\text { Other controlled } \\
\text { variables }\end{array}$} \\
\hline Bank size & 0.09 & 0.88 & $-0.08 * * *$ & -4.13 & 0.16 & 0.81 & 0.38 & 0.18 \\
\hline Bank diversification & $0.23 * * *$ & 7.71 & 0.10 & 0.24 & 0.38 & 0.24 & 0.75 & 0.42 \\
\hline Bank profitability & $-11.07 * *$ & -2.36 & 0.28 & 0.51 & 0.53 & 0.49 & $0.86 * * *$ & 3.73 \\
\hline $\begin{array}{c}\text { Banking sector } \\
\text { development }\end{array}$ & $2.83 * * *$ & 9.17 & $-0.44 * * *$ & -9.88 & $0.39 *$ & 1.97 & 0.55 & 0.51 \\
\hline $\begin{array}{l}\text { Stock market } \\
\text { development }\end{array}$ & 0.06 & 0.04 & 0.01 & 0.32 & 0.75 & 0.09 & 0.18 & 1.19 \\
\hline inflation & $-0.55 * * *$ & -5.82 & $0.032 * * *$ & 8.37 & $0.18 * * *$ & 3.92 & $-0.94 * * *$ & -5.43 \\
\hline GDP growth rate & 0.53 & 0.43 & 0.26 & 0.05 & 0.84 & 0.19 & 0.19 & 0.49 \\
\hline Constant & $0.27 * * *$ & 10.88 & $0.10^{* * *}$ & 7.17 & $0.06^{* * *}$ & 8.55 & $0.21 * * *$ & 6.53 \\
\hline Observations & \multicolumn{2}{|c|}{1100} & \multicolumn{2}{|c|}{1018} & \multicolumn{2}{|c|}{1011} & \multicolumn{2}{|c|}{1010} \\
\hline R-Squared (Within) & \multicolumn{2}{|c|}{0.165} & \multicolumn{2}{|c|}{0.173} & \multicolumn{2}{|c|}{0.181} & \multicolumn{2}{|c|}{0.195} \\
\hline Probability $>\mathrm{F}$ & \multicolumn{2}{|c|}{$13.58 * * *$} & \multicolumn{2}{|c|}{$13.51 * * *$} & \multicolumn{2}{|c|}{$14.14 * * *$} & \multicolumn{2}{|c|}{$13.99 * * *$} \\
\hline
\end{tabular}

Note: $*, * *$ and $* * *$ denote significance at $10 \%, 5 \%$ and $1 \%$ levels, respectively. 
Table 6 The impacts of profitability on competition on bank risk (fixed-effects estimations with credit risk measured by loan loss provisions to total loans and liquidity measured by deposit to total assets) - robust standard errors clustered by banks

\begin{tabular}{|c|c|c|c|c|c|c|c|c|}
\hline & \multicolumn{2}{|c|}{$\begin{array}{c}\text { Dependent variable }= \\
\text { credit risk }\end{array}$} & \multicolumn{2}{|c|}{$\begin{array}{c}\text { Dependent variable }= \\
\text { liquidity risk }\end{array}$} & \multicolumn{2}{|c|}{$\begin{array}{c}\text { Dependent variables= } \\
\text { capital risk }\end{array}$} & \multicolumn{2}{|c|}{$\begin{array}{c}\text { Dependent variable= } \\
\text { insolvency risk }\end{array}$} \\
\hline Independent variables & Coefficient & T-stat & Coefficient & T-stat & Coefficient & T-stat & Coefficient & T-stat \\
\hline \multicolumn{9}{|l|}{ competition variables } \\
\hline $\begin{array}{c}\text { competition (Lerner } \\
\text { index) }\end{array}$ & $-2.19 * * *$ & -7.54 & $1.21 * * *$ & 11.15 & $5.19 * * *$ & 3.87 & $6.16^{* * *}$ & 6.75 \\
\hline \multicolumn{9}{|l|}{$\begin{array}{c}\text { Other controlled } \\
\text { variables }\end{array}$} \\
\hline Bank size & 0.06 & 0.62 & $-0.14 * * *$ & -4.22 & 0.35 & 0.66 & 0.97 & 0.29 \\
\hline Bank diversification & $0.28 * * *$ & 8.73 & 0.18 & 0.24 & 0.44 & 0.46 & 0.21 & 0.77 \\
\hline Bank profitability & $-10.13 * *$ & -2.38 & 0.31 & 0.75 & 0.50 & 0.59 & $0.94 * * *$ & 3.92 \\
\hline $\begin{array}{c}\text { Banking sector } \\
\text { development }\end{array}$ & $2.81 * * *$ & 8.97 & $-0.41 * * *$ & -10.17 & $0.33 * *$ & 2.83 & 0.34 & 0.49 \\
\hline $\begin{array}{l}\text { Stock market } \\
\text { development }\end{array}$ & 0.06 & 0.07 & 0.06 & 0.34 & 0.18 & 0.34 & 0.64 & 0.46 \\
\hline inflation & $-0.51 * * *$ & -6.32 & $0.09 * * *$ & 9.71 & $0.93 * * *$ & 4.32 & $-0.81 * * *$ & -5.84 \\
\hline GDP growth rate & 0.55 & 0.48 & 0.47 & 0.08 & 0.84 & 0.58 & 0.47 & 0.38 \\
\hline Constant & $0.29 * * *$ & 11.24 & $0.21 * * *$ & 8.54 & $0.16^{* * *}$ & 9.12 & $0.63 * * *$ & 8.42 \\
\hline Observations & \multicolumn{2}{|c|}{1100} & \multicolumn{2}{|c|}{1018} & \multicolumn{2}{|c|}{1011} & \multicolumn{2}{|c|}{1010} \\
\hline R-Squared (Within) & \multicolumn{2}{|c|}{0.171} & \multicolumn{2}{|c|}{0.218} & \multicolumn{2}{|c|}{0.234} & \multicolumn{2}{|c|}{0.317} \\
\hline Probability $>\mathrm{F}$ & \multicolumn{2}{|c|}{$14.48 * * *$} & \multicolumn{2}{|c|}{$15.59 * * *$} & \multicolumn{2}{|c|}{$16.86^{* * *}$} & \multicolumn{2}{|c|}{$15.95 * * *$} \\
\hline
\end{tabular}

Note: $* * *$ and $* * *$ denote significance at $10 \%, 5 \%$ and $1 \%$ levels, respectively. 